\title{
FORMUŁA ZASTĘPSTWA GŁOWY PAŃSTWA W ŚWIETLE ART. 57 USTAWY ZASAdNicZEJ Republiki Federalnej Niemiec
}

\section{Zastępstwo prezydenta w czasach Republiki Weimarskiej}

Pierwsze uregulowania normatywne dotyczące instytucji zastępstwa republikańskiej głowy państwa pojawiły się w Niemczech w okresie funkcjonowania Republiki Weimarskiej. Wprowadzono je na gruncie Konstytucji z 1919 r., uchwalonej zaraz po upadku monarchii Wilhelma II. Opierając się na zasadach ustroju republikańskiego, konstytucja ta nadała władzom państwowym zupełnie nowy kształt. Dotyczyło to - co oczywiste - także instytucji głowy państwa, która odtąd zyskała obieralny i kadencyjny charakter ${ }^{1}$. Wobec wprowadzenia takiej konstrukcji prawnej, nieuniknione stało się ustanowienie norm przewidujących ewentualność zastępstwa prezydenta na wypadek zaistnienia przeszkody w sprawowaniu urzędu. $\mathrm{W}$ tej materii stosowne regulacje zawarte zostały $\mathrm{w}$ art. 51 konstytucji.

Cechą charakterystyczna wskazanego przepisu była daleko idąca oszczędność treści normatywnej. Unikając kazuistyki, ustrojodawca ograniczył się w tym zakresie do wskazania podmiotu dysponującego mandatem zastępcy oraz okoliczności uruchamiania zastępstwa. Zgodnie z nim funkcję prezydenckiego zastępcy wykonywać miał kanclerz Rzeszy. Zastępstwo to powstawało z mocy prawa, wobec wystąpienia przeszkody (Verhinderung) uniemożliwiającej sprawowane urzędu przez głowę pań-

* Dr, Uniwersytet Rzeszowski, grzegorz.pastuszko@op.pl.

1 Szerzej na ten temat zob. K. Dunaj, Weimarski model prezydentury, Warszawa 2010, s. $47-60$. 
stwa. W założeniu miało ono charakter tymczasowy. Jeśli jednak istniało przypuszczenie, że przeszkoda, o jakiej mowa, będzie trwać przez dłuższy czas (längere Zeit) albo jeśli doszło do opróżnienia urzędu Prezydenta Rzeszy przed upływem kadencji, wówczas wszystkie kwestie związane z zastępstwem uregulowane miały być w odrębnej, poświęconej wyłącznie temu zagadnieniu, ustawie. Ocena dotycząca kwestii charakteru zaistniałej przeszkody (tj. ustalenia czy będzie to przeszkoda długotrwała) należała do Reichstagu². Zastępstwo takie realizowane było do momentu wyboru nowego Prezydenta Rzeszy ${ }^{3}$.

Tak skonstruowanej instytucji zastępstwa ówczesna doktryna nie szczędziła słów krytyki. Wskazywano mianowicie nie tylko na niebezpieczeństwo związane ze zbyt daleko idącą koncentracją władzy wykonawczej w rękach jednej osoby, ale zarzucano wręcz, że taki mechanizm podważa istotę konstytucyjnego systemu rządów ${ }^{4}$. Ważkim argumentem skierowanym przeciw przyjętemu rozwiązaniu było to, że rząd, a więc również jego szef, podlegali odpowiedzialności politycznej ze strony Reichstagu. Stwierdzał to art. 54 Konstytucji z 1919 r., według którego rząd i ministrowie swą misję ustrojową wypełniać mogli pod warunkiem istnienia parlamentarnego zaufania. Jego cofnięcie powodowało - przynajmniej według dominującej linii interpretacyjnej - obowiązek ustąpienia rządu. Jeśli zatem decyzja o odwołaniu rządu nałożyłaby się na okres trwania zastępstwa, wówczas oznaczałoby to równocześnie pozbawienie państwa prezydenckiego zastępcy ${ }^{5}$. Odrębny problem w tym zakresie sta-

2 G. Anschütz, Die Verfassung des Deutschen Reichs vom 11. August 1919 (Kommentar), Art. 51, Berlin 1929, s. 253.

3 Treść art. 51 miała następujące brzmienie:

„1. Der Reichspräsident wird im Falle seiner Verhinderung durch den Reichskanzler vertreten. Dauert die Verhinderung voraussichtlich längere Zeit, so ist die Vertretung durch ein Reichsgesetz zu regeln.

2. Das gleiche gilt für den Fall einer vorzeitigen Erledigung der Präsidentschaft bis zur Durchführung der neuen Wahl".

${ }^{4}$ F. Stier-Somlo, Deutches Reichs- und Landesstaatsrecht, Tom 1, Berlin 1924, s. 604.

${ }^{5}$ Trzeba jednak zaznaczyć, że w literaturze przedmiotu formułowano wykładnię, która negowała obowiązek ustąpienia rządu na skutek wyrażenia wotum nieufności wyrażonego przez parlament. Zdaniem części przedstawicieli nauki o dymisji rządu miał ostatecznie decydować Prezydent Rzeszy; zob. H. Herrfahrdt, Die Kabinettsbildung nach der Weimarer Verfassung unter dem Einfluss der politischen Praxis, Berlin 1927, s. 19-20; W warunkach istnienia zastępstwa prezydenta, przy zachowaniu zasygnalizowanych założeń, skuteczność uchwały Reichstagu w przedmiocie wotum nieufności byłaby zatem uzależniona od stanowiska samego Kanclerza Rzeszy; zob. przykładowo: J. Hatscheck, Deutsches und preussisches Staatsrecht, Berlin 1922, s. 543. 
nowił fakt, że parlament, korzystając z konstytucyjnego uprawnienia do wyrażenia rządowi nieufności, zyskiwał możliwość oceny wszystkich posunięć Kanclerza Rzeszy, które ten realizował jako prezydencki zastępca. Biorąc pod uwagę obowiązującą w konstytucji z 1919 r. zasadę nieodpowiedzialności politycznej głowy państwa przed parlamentem, mogło to tak w wymiarze doktrynalnym, jak i praktycznym wywoływać uzasadnione wątpliwości.

Z brzmienia art. 51 Konstytucji wynikało, że instytucja zastępstwa miała postać zastępstwa sede plena oraz sede vacante. W pierwszym przypadku funkcję prezydenckiego zastępcy sprawował Kanclerz Rzeszy, w drugim zaś osoba wskazana przez parlament $\mathrm{w}$ ramach uchwalonej $\mathrm{w}$ tym celu specjalnej ustawy (teoretycznie mógł to być również Kanclerz' ${ }^{6}$. Wykonywanie zastępstwa sede plena oparte było bezpośrednio na przepisach konstytucji, przy czym w piśmiennictwie prawniczym wyraźnie zaznaczano, że prezydencki zastępca korzysta $\mathrm{w}$ tym zakresie $\mathrm{z}$ pełni kompetencji przyznanych głowie państwa ${ }^{7}$. Z kolei wykonywanie zastępstwa sede vacante musiało pozostawać $\mathrm{w}$ zgodzie $\mathrm{z}$ regulacjami wspomnianej ustawy, która - co także eksponowano w doktrynie - nie mogła naruszać postanowień ustawy zasadniczej ${ }^{8}$. Jest natomiast rzeczą znamienną że niemiecki ustrojodawca tworząc obydwa wskazane modele zastępstwa, nie określił in concreto katalogu przeszkód wyłączających możliwość sprawowania urzędu przez Prezydenta Rzeszy. Brak ten rekompensowały do pewnego stopnia ustalenia doktryny. Ogólnie rzecz biorąc, przeszkody dzielono na przeszkody tymczasowe i przeszkody trwałe. W grupie tych pierwszych znalazły się przeszkody prawne oraz przeszkody faktyczne. Przeszkodą prawną była przeszkoda wynikająca z art. 43 konstytucji z 1919 r., który przewidywał procedurę złożenia z urzędu Prezydenta Rzeszy. Otóż, zgodnie z brzmieniem wskazanej regulacji decyzję $\mathrm{w}$ tej sprawie podejmował Naród, co jednak uwarunkowane było wcześniejszym wydaniem przez Reichstag stosownej uchwały. Uchwała taka zapadała większością 2/3 głosów ogólnej liczby członków Reichstagu i niosła ze sobą daleko idące skutki prawne. Oprócz uruchomienia procedury głosowania

${ }^{6}$ F. Stier-Somlo, Die Verfassungsurkunde der Vereinigten Staaten von Deutschland $<$ Demokratische Reichsrepublik> : ein Entwurf mit Begründung, Tübingen, 1919, s. 603.

${ }^{7}$ K. Fritsch, Die Funktionen des Reichspräsidenten nach der neuen Reichsverfassung vom 11. August 1919 verglichen mit den Funktionen des ehemaligen deutschen Kaisers, Stettin 1921, s. 19.

${ }^{8}$ G. Weisser, Die Stellvertretung des Reichspräsidenten unter Berücksichtigung des ausländischen Staatsrecht, Kiel 1926, s.55. 
ludowego, powodowała bowiem także zawieszenie Prezydenta w sprawowanym urzędzie, które oznaczało konieczność objęcia tej funkcji przez zastępcę w trybie art. 51 ustawy zasadniczej9. Do przeszkód faktycznych zaliczano przede wszystkim chorobę, przyjmującą postać zarówno dolegliwości fizycznych, jak i psychicznych; długotrwałą wizytę zagraniczną Prezydenta; długotrwałe zniknięcie; niewolę, etc. ${ }^{10}$. Bardziej rozlegle prezentował się katalog przeszkód trwałych, związanych z przedterminowym opróżnieniem stanowiska Prezydenta Rzeszy. Składały się nań mianowicie takie okoliczności jak: 1) śmierć; 2) rezygnacja ze sprawowanego urzędu; 3) naruszenie zasady incompatibilitas; 3) pozbawienie funkcji na mocy prawomocnego orzeczenia Państwowego Trybunału Rzeszy; 4) złożenie urzędu Prezydenta w głosowaniu ludowym; 5) nieważność wyboru; 5) utrata praw obywatelskich $w$ trakcie pełnienia urzędu ${ }^{11}$.

Dla porządku odnotujmy, że jedyny przypadek uruchomienia zastępstwa w całym okresie funkcjonowania Republiki Weimarskiej wiązał się ze śmiercią prezydenta Friedricha Eberta, mającej miejsce 28 lutego 1925 r. Jeszcze w tym samym dniu obowiązki głowy państwa przejął ówczesny kanclerz Rzeszy Hans Luther, który jednak jako prezydencki zastępca nie działał długo. Dnia 10 marca 1925 r. bowiem Reichstag, korzystając z przepisów konstytucji, uchwalił odrębną ustawę, przekazującą zastępstwo na rzecz przewodniczącego Sądu Rzeszy Waltera Simonsa. Nowy wykonawca prezydenckich obowiązków z pełnionej funkcji zwolniony został dopiero 12 maja 1925 r., z chwilą objęcia urzędu przez uprzednio wybranego prezydenta Paula von Hindenburga ${ }^{12}$.

Przedstawiony w powyższych rozważaniach przepis art. 51 konstytucji zachował pierwotny kształt aż do fazy schyłkowej Republiki Weimarskiej. Zmieniono go dopiero na mocy nowelizacji ustawy zasadniczej z 17 grudnia 1932 r., której treść mocno odbiegała od rozwiązań obowiązujących w poprzednim stanie prawnym. Przede wszystkim nowy przepis odrzucił zasadę wykonywania funkcji zastępcy prezydenta przez Kanclerza Rzeszy, oddając niniejszym zastępstwo w ręce Prezesa Sądu Rzeszy. Jak wskazuje się w literaturze przedmiotu, wprowadzenie tego unormowania, zaproponowanego notabene przez obecną $\mathrm{w}$ parlamencie NSDAP, podyktowane było chęcią osłabienia pozycji ówczesnego Kanclerza Kurta von Schleiche-

\footnotetext{
9 T. Hohhof, Die Stellvertretung des Reichspräsidenten, Hamburg 1927, s. 17-18.

10 Tamże, s. 19-20.; zob. także: G. Weisser, Die Stellvertretung...., s. 39.

11 Tamże, s. 29-33.

${ }^{12}$ K. Dunaj, Weimarski..., s. 60.
} 
$\mathrm{ra}^{13}$. Jednocześnie ustrojodawca zrezygnował z konieczności uchwalania odrębnej ustawy w sytuacji przedterminowego opróżnienia urzędu głowy państwa. W świetle przyjętych uregulowań, przez cały okres występowania przeszkody, zarówno tymczasowej, jak i trwałej, w charakterze zastępcy miał działać Prezes Sądu Rzeszy. W ten sposób Reichstag pozbawił się prawa do decydowania o kwestii zastępstwa, mimo że tego rodzaju rozwiązanie - jak sygnalizowano w piśmiennictwie - odpowiadało w pełni demokratycznej naturze ustroju Republiki Weimarskiej ${ }^{14}$.

Nowe unormowania nie utrzymały się jednak długo. Dnia 24 marca 1933 r. zdominowany przez nazistów Reichstag uchwalił słynną ustawę o pełnomocnictwach (Ermächtigungsgesetz), która funkcję zastępcy na powrót choć w zupełnie innych warunkach politycznych - powierzyła Kanclerzowi Rzeszy. Był to zresztą również stan krótkotrwały. Przeszło rok później, 1 sierpnia 1934 r., na dzień przed śmiercią prezydenta Paula von Hindenburga, dokonała się fuzja stanowiska Kanclerza i Prezydenta Rzeszy. Moment ten traktowany jest jako cezura czasowa formalnego ustanowienia w hitlerowskich Niemczech dyktatury. Jedną z prawnoustrojowych konsekwencji takiego obrotu spraw było zniesienie instytucji zastępcy prezydenta.

\section{Zastępstwo prezydenta Republiki Federalnej Niemiec}

W obecnym stanie prawnym problematyka zastępstwa prezydenta $\mathrm{w}$ urzędzie uregulowana została na gruncie art. 57 niemieckiej ustawy zasadniczej, głoszącego iż „,w przypadku niemożności sprawowania przez prezydenta urzędu lub przedwczesnego zakończenia kadencji jego kompetencje przejmuje przewodniczacy Bundesratu"15. Należy zaznaczyć, że przepis ten do dnia dzisiejszego zachował swój pierwotny kształt, obowiązując niezmiennie od 1949 r. Rzecza, która w jego konstrukcji w sposób szczególny zwraca uwagę, jest ograniczony zakres treściowy. Istotnie ustrojodawca,

${ }^{13}$ N. Patok, Wahrnehmung der Befugnisse des Bundespräsidenten durch den Präsidenten des Bundesrates. Artikel 57 GG, München 1966, s. 9.

${ }^{14}$ W. Mettke, Die Verantwortlichkeit des Reichsgerichtsspräsidenten als Stellvertrete des Reichspräsidenten und deren Geltenmachung, Breslau 1934, s. 39.

${ }^{15}$ Grundgesetz für die Bundesrepublik Deutschland in der im Bundesgesetzblatt Teil III, Gliederungsnummer 100-1, veröffentlichten bereinigten Fassung, das zuletzt durch Artikel 1 des Gesetzes vom 23. Dezember 2014 (BGBl. I S. 2438) geändert worden ist. 
tworząc podstawę prawną dla działania prezydenckiego zastępcy, posłużył się - podobnie zresztą jak to miało miejsce w Republice Weimarskiej - regulacją ramowa o małym stopniu szczegółowości. Przez długie lata, w tym zwłaszcza w początkowym etapie funkcjonowania ustroju RFN, to lapidarne ujęcie było źródłem szeregu interpretacyjnych dylematów, które usuwano w drodze praktyki ustrojowej, względnie poprzez tezy formułowane w piśmiennictwie.

Na tle redakcji wskazanego unormowania prima facie wyłaniają się trzy zasadnicze spostrzeżenia. Otóż po pierwsze, jak wynika z konstytucyjnej dyrektywy, ustrojodawca oddaje funkcję prezydenckiego zastępcy w ręce organu, który instytucjonalnie związany jest (przynajmniej gdy idzie o szczebel federalny) z legislatywą, co skądinąd stanowi wyraźne odstępstwo od wzorca wypracowanego w Republice Weimarskiej. Po drugie, uwagę zwraca lapidarny sposób uregulowania kwestii przesłanek warunkujących objęcie stanowiska prezydenckiego zastępcy, pozbawiony jakiejkolwiek próby ich skatalogowania lub też przynajmniej normatywnej egzemplifikacji. Po trzecie wreszcie, charakterystyczny jest brak przepisów określających tryb uruchamiania zastępstwa. W pewnych sytuacjach zagadnienie to może wywoływać poważne wątpliwości.

\section{Stanowisko prawne zastępcy Prezydenta RFN}

Jak już wspomniano, powierzenie stanowiska zastępcy prezydenta szefowi Bundesratu było $\mathrm{w}$ niemieckim konstytucjonalizmie rozwiązaniem nowym. W trakcie prac nad treścią postanowień konstytucji z 1949 r. składano w tym zakresie różne propozycje. Poważnie rozważany był w szczególności projekt, w myśl którego funkcja zastępcy prezydenta miała być wykonywana przez Prezesa Związkowego Trybunału Konstytucyjnego. Pomysł ten ostatecznie nie doczekał się realizacji, co wynikało z dwóch przyczyn. Otóż po pierwsze, wywoływał on negatywne skojarzenia ze znowelizowanymi przepisami Konstytucji Weimarskiej, która - o czym była mowa wcześniej - w 1932 r. prezydenckim zastępcą uczyniła Prezesa Sądu Rzeszy ${ }^{16}$. Po drugie zaś uznano, że przy tak pomyślanej

${ }^{16}$ R. Pitschas, Die Vertretung des Bundespräsidenten durch den Präsidenten des Bundesrates, Der Staat Bd. 12, 1973, s. 185. 
instytucji zastępstwa istnieje poważne ryzyko związane z powstawaniem konfliktu interesów w sytuacji, gdy przeciwko prezydenckiemu zastępcy wszczęte zostanie postępowanie, będące efektem wniesienia skargi do Federalnego Trybunału Konstytucyjnego ${ }^{17}$. Co ciekawe natomiast, podobnej refleksji zabrakło w odniesieniu do zaakceptowanej ostatecznie koncepcji zastępstwa przewodniczącego Bundesratu. Przypominając okoliczności prac nad konstytucją z 1949 r. R. Pitschas zauważa, że w trakcie prac nad rozwiązaniami ustawy zasadniczej dostrzegano wprawdzie wady tego rozwiązania, niemniej dyskusja jemu poświęcona przeprowadzona została na tyle szybko, iż nie zdołano w sposób wnikliwy rozważyć wszystkich „za" i „przeciw"18.

Gdy idzie o pozycję prawną przewodniczącego Bundesratu, należy zauważyć, iż jest on wybierany przez izbę na okres jednorocznej kadencji (art. 52 ust. 1 ustawy zasadniczej). Co istotne, wybór ten może dotyczyć wyłącznie osoby będącej członkiem izby ( 55 regulaminu Bundesratu W nawiązaniu do art. 52 ust. 1 ustawy zasadniczej $)^{19}$. W praktyce ustrojowej na tle stosowania sygnalizowanej regulacji ukształtował się trwały i konsekwentnie przestrzegany zwyczaj, według którego funkcję przewodniczącego Bundesratu przekazuje się kolejno, w ramach mechanizmu rotacji, wszystkim szefom rządów krajowych ${ }^{20}$. Wynika stąd, że konstytucyjny zastępca prezydenta jest nie tylko organem federalnej legislatywy, ale na poziomie krajowym występuje także jako przedstawiciel władzy wykonawczej. Tak daleko idącą komasację funkcji do pewnego stopnia równoważy - jak można sądzić - regulaminowe rozwiązanie, statuujące zasadę, że obowiązki przewodniczącego Bundesratu w okresie sprawowania zastępstwa prezydenta ex lege muszą zostać przekazane (w pierwszej kolejności pierwszemu) wiceprzewodniczącemu izby ${ }^{21}(\S 7$ ust. 1 regulaminu Bundesratu). Ograniczeniu nadmiernej aktywności przewod-

17 R. Wahl, Stellvertretung im Verfassungsrecht, Berlin 1971, s. 111-112.

${ }^{18}$ R. Pitschas, Die Vertretung..., s. 184-185.

${ }_{19}$ Geschäftsordnung des Bundesrates in der Fassung der Bekanntmachung vom 26. November 1993 (Bundesgesetzblatt Teil I Seite 2007), zuletzt geändert durch Beschluss des Bundesrates vom 8. Juni 2007 (Bundesgesetzblatt Teil I Seite 1057) (Bundesrats-Drucksache 310/07 [Beschluss]; wykorzystane źródło: http://www.bundesrat.de/DE/aufgaben/ recht/go/gonode.html;jsessionid=05AD2346F135ECC32B7369D3CE53AE68.2_cid382\#doc4353624bodyText2.

${ }^{20}$ P. Czarny, Bundesrat. Między niemiecka tradycja a europejska przyszłościa, Warszawa 2000, s.71, s. 68 .

${ }^{21}$ J. Isensee, P. Kirchhof, Parlament Republiki Federalnej Niemiec, Warszawa 1995, s. 229. 
niczącego Bundesratu służy także ukształtowana w praktyce ustrojowej reguła, według której w okresie sprawowania zastępstwa, ze względu na dbałość o zachowanie pozycji neutralnej politycznie, nie czyni on użytku z uprawnień wynikających z mandatu parlamentarnego, takich jak udział $\mathrm{w}$ debatach czy głosowaniach odbywających się w izbie ${ }^{22}$.

W piśmiennictwie podkreśla się, że objęcie stanowiska zastępcy prezydenta nie jest uprawnieniem, ale obowiązkiem przewodniczącego Bundesratu ${ }^{23}$. Jednocześnie formułuje się pogląd, według którego przy realizowaniu funkcji co do zasady dysponuje on pełnią konstytucyjnych kompetencji prezydenta. O braku jakichkolwiek ograniczeń kompetencyjnych świadczyć ma tu - dodajmy - milczenie ustawy zasadniczej. Jestjednak rzeczą wymagającą podkreślenia, że w praktyce ustrojowej ukształtował się zwyczaj polegający na przekazywaniu w określonych okolicznościach przez prezydenta swemu zastępcy jedynie wyodrębnionej części prezydenckich kompetencji. Konkretnie rzecz biorąc, ma to miejsce w sytuacji, gdy udający się w ramach misji dyplomatycznej prezydent wyjeżdża $\mathrm{z}$ wizytą zagraniczną do innego państwa. $\mathrm{W}$ tym celu kieruje on na ręce przewodniczącego Bundesratu stosowne pismo, które dodatkowo, dla swej skuteczności, musi być objęte kontrasygnatą ministra właściwego ds. zagranicznych ${ }^{24}$. Nie może natomiast prezydent wydawać wykonującemu jego obowiązki przewodniczącemu Bundesratu jakichkolwiek dyrektyw dotyczących sposobu wykonywania funkcji zastępczej. W tym zakresie przewodniczący Bundesratu pozostaje w pełni swobodny ${ }^{25}$.

Należy zaznaczyć, że wynikająca z okresowej rotacji zmiana na stanowisku przewodniczącego Bundesratu powoduje równoczesną zmianę na stanowisku prezydenckiego zastępcy ${ }^{26}$. Tego rodzaju interpretacja art. 57 ustawy zasadniczej opiera się na słusznym, jak można sądzić, założeniu, według którego funkcja zastępcy przypisana jest temu, kto $\mathrm{w}$ danym momencie piastuje mandat szefa drugiej izby niemieckiego parlamentu. Inaczej natomiast przedstawia się sytuacja, gdy z jakichś powodów nie tylko prezydent, ale także przewodniczący Bundestagu, nie są w stanie

${ }^{22}$ Wspomina o tym R. Wahl, Stellvertretung..., s. 122.; odnotujmy, że zwyczaj ten pozostaje aktualny także dzisiaj.

${ }^{23}$ N. Paterok,.Die Wahrnehmung der Befugnisse des Bundespräsidenten durch den Präsidenten des Bundesrats, Art. 57 GG, München 1966, s. 21.

${ }^{24}$ M. Bożyk, Instytucja Prezydenta Republiki Federalnej Niemiec, Warszawa 2007, s. 79.

${ }^{25}$ B. Pieroth, Art. 57, [w:] H. Jarass, B. Pieroth (red.), Grundgesetz für die Bundesrepublik Deutschland, , Aufl. 4, München 1997, s. 666.

${ }^{26}$ N. Paterok, Die Wahrnehmung..., s. 22. 
w jednym czasie wykonywać swoich obowiązków. Nałożenie się na siebie wskazanych scenariuszy rodzi poważny dylemat, gdyż zawarte w ustawie zasadniczej przepisy nie dostarczają $\mathrm{w}$ tym względzie żadnych jasnych wskazówek. Pewnym wyjściem z sytuacji, jakie może się tu nasuwać, jest powierzenie funkcji zastępcy wiceprzewodniczącemu Bundesratu. Taki kierunek interpretacji obowiązujących przepisów ma w niemieckiej doktrynie prawa konstytucyjnego swoich zwolenników ${ }^{27}$, choć nie brakuje też głosów krytycznych, podważających jego zasadnośćn ${ }^{28}$. Wyraziciele tego ostatniego poglądu nie bez racji wywodza, iż przeszkodą jest tu konkretnie wyłącznie regulaminowe umocowanie wiceprzewodniczącego Bundesratu. Otóż w myśl prezentowanej argumentacji, regulacje regulaminowe, ze względu na prawną charakterystykę regulaminu, wynikającą z zasady autonomii parlamentu, nie mogą odnosić się do sfery stosunków zewnętrznych, w efekcie czego wiceprzewodniczący Bundesratu, pozbawiony konstytucyjnej legitymacji, a bazujący wyłącznie na legitymacji regulaminowej, nie jest władny wykonywać funkcji konstytucyjnego zastępcy. Ocena ta - zaznaczmy na marginesie - idzie "pod włos” dotychczasowej praktyce ustrojowej, w której zasadniczo zaaprobowano sprawowanie zastępstwa przez wiceprzewodniczącego Bundesratu. Przykładem jest tu przypadek prezydentury Heinricha Lübke, kiedy to ze względu na zbieg urlopów prezydenta oraz przewodniczącego Bundesratu Kurta Kiesingera, w okresie od 15 do 31 sierpnia 1963 r., obowiązki głowy państwa wypełniał wiceprzewodniczący drugiej izby niemieckiego parlamentu Alfons Goppel.

Jednym z największym problemów związanych z instytucją zastępstwa prezydenta, nie tylko zresztą w RFN, jest problem konfliktu ról, $\mathrm{w}$ jaki popada przewodniczący Bundestagu z chwilą objęcia stanowiska zastępcy. Konflikt ten - co oczywiste - wynika z usytuowania prawnego podmiotu zastępowanego oraz podmiotu zastępującego w odrębnych segmentach władzy państwowej, przy jednoczesnym wytworzeniu między nimi wzajemnych, mających normatywną postać, zależności. Jest on wprawdzie usprawiedliwiony nadzwyczajnym charakterem instytucji zastępstwa, nie zmienia to jednak faktu, że w płaszczyźnie jurydycznej może spowodować poważne zaburzenia w funkcjonowaniu mechanizmu władzy państwowej, w tym w szczególności zaburzenie „wmontowane-

${ }^{27}$ B. Pieroth, art. $57 \ldots$, s. 666.

${ }^{28}$ N. Paterok, Die Wahrnehmung...., s. 25. 
go" w zasadę trójpodziału władzy mechanizmu wzajemnego równoważnia się władz ${ }^{29}$.

W doktrynie prawa konstytucyjnego zwraca się uwagę na kilka kompetencji prezydenckich, niosących ze sobą zagrożenie wywołania konfliktu ról $\mathrm{w}$ momencie, gdy realizuje je przewodniczący Bundesratu. W pierwszej kolejności nasuwają się tu takie kompetencje jak podpisywanie ustaw (art. 82 ust. 1 ustawy zasadniczej), wprowadzanie stanu wyższej konieczności ustawodawczej (art. 81 ust. 1 ustawy zasadniczej) czy też wiążące żądanie zwołania posiedzenia Bundestagu (art. 39 ust. 3 ustawy zasadniczej). We wszystkich przypadkach przewodniczący Bundesratu narażony jest na podejmowanie decyzji, od których zależeć mogą polityczne interesy reprezentowanej przez niego instytucji, tj. Bundesratu ${ }^{30}$. Gdy idzie o podpisywanie ustawy, należy zauważyć, że prezydencki zastępca, ze względu na wykonywaną funkcję $\mathrm{w}$ parlamencie, mógłby mieć problem z neutralną oceną tego, czy ustawa, jaka wpłynęła do podpisu, wymaga jeszcze zgody Bundesratu, czy też winna być ona - wedle sugestii rządu i Bundestagu - bezpośrednio podpisana ze względu na upływ terminów służących Bundesratowi do wyrażenia sprzeciwu. Podobna obawa dotyczy sytuacji ewentualnego wprowadzenia przez zastępcę głowy państwa stanu wyższej konieczności ustawodawczej, który - przedstawiając rzecz w sposób dalece uproszczony - powoduje wyraźne wzmocnienie uprawnień Bundesratu w dziedzinie postępowania ustawodawczego ${ }^{31}$. Nie inaczej jest $\mathrm{w}$ przypadku zwoływania posiedzenia Bundestagu, gdy posiedzenie to z jakichś powodów daje Bundesratowi polityczną korzyśćc ${ }^{2}$. Obok wskazanych kompetencji, źródłem konfliktu interesów może stać się także wykonywanie przez prezydenckiego zastępcę kompetencji wynikającej z art. 60 ust. 1 ustawy zasadniczej. Zgodnie z brzmieniem tego przepisu prezydent powołuje i odwołuje sędziów sądów federalnych, urzędników federalnych oraz oficerów i podoficerów. Jak podnosi się $\mathrm{w}$ piśmiennictwie, istnieje $\mathrm{w}$ tym względzie poważne ryzyko, że decydujący o personaliach szef rządu określonego kraju związkowego, kie-

${ }^{29} \mathrm{~W}$ piśmiennictwie niemieckim problem konfliktu ról przeanalizowano także w odniesieniu do innych, traktowanych jako potencjalni zastępcy, podmiotów, tj. kanclerza, przewodniczącego Bundestagu, a także przewodniczącego Federalnego Trybunału Konstytucyjnego; zob. szerzej na ten temat: R. Herzog, Art. 57, [w:] T. Maunz, G. Dürig (red.), Grundgesetz. Kommentar, München 2014, s. 4.

${ }^{30}$ P. Czarny, Bundesrat..., s. 71.

${ }^{31}$ Tamże, s. 71.

${ }^{32}$ R. Pitschas, Die Vertretung..., s. 194. 
rował się będzie nie tyle obiektywną oceną kwalifikacji danej osoby, co kryterium interesu partyjnego względnie kryterium interesu ministerialnej biurokracji ${ }^{33}$. Na koniec można jeszcze zwrócić uwagę na potencjalne zagrożenie zaistnienia konfliktu ról w związku z obowiązywaniem art. 61 ustawy zasadniczej, który obu izbom niemieckiego parlamentu daje możliwość oskarżenia prezydenta, a więc również i jego zastępcę, przed Federalnym Trybunałem Konstytucyjnym z powodu umyślnego naruszenia przepisów ustawy zasadniczej lub innej ustawy federalnej. Nie da się mianowicie wykluczyć, iż w takim przypadku u podstaw decyzji izb, w tym w szczególności Bundestagu, leżeć będą inne niż stricte prawne motywacje ${ }^{34}$.

\section{Przeszkody w sprawowaniu urzędu}

Konstytucja RFN z 1949 r. podobnie jak czyniła to jej poprzedniczka z okresu Republiki Weimarskiej, wprowadza dwie kategorie przeszkód w sprawowaniu urzędu przez głowę państwa, tj. przeszkody przemijające (Verhinderung) oraz przeszkody trwałe, związane z opróżnieniem urzędu (vorzeitige Erledigung).

Przeszkody przemijające wiążą się z tymczasową niezdolnością prezydenta do wypełniania obowiązków. Ich relewantną cechą jest to, że mają odwracalny i przejściowy charakter ${ }^{35}$. W literaturze przedmiotu dzieli się je na przeszkody faktyczne oraz przeszkody prawne. W kręgu tych pierwszych wymieniane są przykłady takie jak urlop, pobyt zagraniczny, choroba uprowadzenie, niewola ${ }^{36}$. Z kolei jako przeszkodę prawną wskazuje się wniesienie przez Bundestag bądź Bundesrat skargi do Federalnego Trybunału Konstytucyjnego przeciwko głowie państwa z powodu umyślnego naruszenia przepisów ustawy zasadniczej (art. 61 ust. 1 ustawy zasadniczej). Nie sama skarga jest tu jednak - podkreślmy - okolicznością wywołującą stan niemożności sprawowania urzędu, o tym bowiem, czy ustanowienie zastępstwa będzie konieczne, decyduje ostatecznie Trybu-

33 Tamże, s. 194.

34 Tamże, s. 194.

35 D.C.Umbach, Artikel 57, [w:] D.C. Umbach, T. Clemens (red.), Grungesetz. Mitarbeiterkommentar, Tom II, Art. 38-146 GG, Heidelberg 2002, s. 305.

36 Tamże, s. 351. 
nał, który na tę okoliczność wydaje specjalne, tymczasowe zarządzenie (ze skutkiem w postaci zawieszenia prezydenta) (art. 61 ust. 2 ustawy zasadniczej).

Podobnie jak w przypadku przeszkód przemijających, konstytucja nie wprowadza także odrębnego katalogu przeszkód trwałych. Z logicznego punktu widzenia należy przyjąć, że bezpośrednim następstwem wystąpienia przeszkody tego rodzaju jest opróżnienie urzędu prezydenta przed upływem 5 letniej kadencji, o jakiej mowa w art. 54 ust. 2 ustawy zasadniczej. W literaturze przedmiotu wymienia się tu przede wszystkim śmierć, a także rezygnację głowy państwa, choć w tym ostatnim przypadku można uniknąć konieczności zastępstwa, jeśli prezydent, wyrażający zamiar złożenia swojej funkcji, z decyzją o rezygnacji poczeka do dnia, w którym wybrany zostanie nowy prezydent ${ }^{37}$. W taki sposób w dniu 30 czerwca 1969 r. zrzekł się urzędu prezydent Heinrich Lübke. Z konsekwencją w postaci ustanowienia zastępstwa rezygnację składali natomiast prezydent Horst Köhler dnia 31 maja 2010 r. oraz prezydent Christian Wulff dnia 17 lutego 2012 r. Do innych przyczyn przeszkód trwałych zalicza się także orzeczenie Federalnego Trybunału Konstytucyjnego w przedmiocie złożenia prezydenta z urzędu, wydawane w trybie art. 61 ust. 2 konstytucji, utratę prawa wybieralności (będącej efektem utraty obywatelstwa niemieckiego, czynnego prawa wyborczego, czy też prawa do sprawowania funkcji publicznych), oraz przypadki ciężkich, nieuleczalnych chorób (np. ślepota, paraliż, niezdolność chodzenia) ${ }^{38}$. Z pewnymi zastrzeżeniami doktryna sytuuje $\mathrm{w}$ tej grupie przypadek naruszenia przez prezydenta art. 55 konstytucji, statuującego zasadę incompatibilitas. W świetle wskazanej regulacji prezydent nie może: 1) przynależeć do rządu lub do jakiejkolwiek jednostki ustawodawczej Federacji lub kraju związkowego, 2) wykonywać żadnego płatnego urzędu, żadnej działalności gospodarczej i żadnego zawodu, 3) być członkiem kierownictwa lub rady nadzorczej przedsiębiorstwa zarobkowego. W razie złamania któregokolwiek z wymienionych zakazów, dochodzi do opróżnienia urzędu ${ }^{39}$. Wreszcie jako sui generis przeszkodę związaną z przedwczesnym zwolnieniem stanowiska prezydenta traktuje się sytuację, kiedy z jakiejś przyczyny wybór

${ }^{37}$ H.Butzer, Art. 57 GG, [w:] B. Schmidt-Bleibtreu, F. Klein (red.), Kommentar zum Grundgesetz, Köln 2011, s. 1230.

38 Tamże, s. 1229.

${ }^{39}$ Nie ma jednak jasności co do tego, czy wskazana okoliczność powoduje automatycznie wakat; zob. tamże, s. 1228. 
nowego prezydenta nastąpi już po wygaśnięciu kadencji poprzednika. W okresie między tymi zdarzeniami konieczne staje się ustanowienie zastępstwa, które sprawowane jest - co oczywiste - w warunkach prezydenckiego wakatu ${ }^{40}$.

\section{Moment uruchamiania oraz okres trwania zastępstwa}

Konstytucja RFN nie przewiduje klarownych wskazówek co do tego, czyją inicjatywą jest uruchomienie procedury zastępstwa. Oczywiście takie wskazówki nie są konieczne, jeśli dochodzi do opróżnienia urzędu prezydenta. Nie ulega bowiem kwestii, że pierwszy krok w takiej sytuacji należy do przewodniczącego Bundesratu. W sposób o wiele bardziej złożony przedstawia się natomiast przypadek, gdy konieczność ustanowienia zastępstwa spowodowana jest zaistnieniem jednej z przeszkód przemijających. Tutaj brak normatywnych rozstrzygnięć może prowadzić do interpretacyjnych wątpliwości. Co do zasady, jak się wydaje, elastyczna treść art. 57 ustawy zasadniczej pozwala przyjąć, że inicjatywa w omawianym zakresie przysługuje zarówno prezydentowi, jak i przewodniczącemu Bundesratu. Na takim stanowisku stoi niemiecka doktryna, która zastrzega jednocześnie, że korzystanie ze wskazanej inicjatywy uzależnione jest od zaistniałego kontekstu sytuacyjnego i charakteru danej przeszkody. W podejściu tym górę bierze zasada, w myśl której pierwsze posunięcie należy do przewodniczącego Bundesratu tylko wówczas, jeśli prezydent nie może sam podjąć stosownych działań. I tak, gdy idzie o wizyty zagraniczne prezydenta, a także jego pobyty $\mathrm{w}$ ramach odpoczynku urlopowego, zgodnie przyjmuje się, iż o ustanowieniu zastępcy przy tych scenariuszach przesądza prezydent ${ }^{41}$. Z kolei przypadek uprowadzenia czy niewoli prezydenta należą do przeszkód, które wymagają samodzielnej reakcji przewodniczącego Bundestagu. Najbardziej złożona jest natomiast sytuacja związana z chorobą prezydenta. W doktrynie niemieckiej uważa się mianowicie, że działanie prezydenta i przewodniczącego Bundestagu w obliczu takiego stanu rzeczy determinuje charakter danego schorzenia. W przypadku choroby lekkiej, ograniczającej

${ }^{40}$ R. Herzog, Art. 57..., s. 4.

${ }^{41}$ N. Paterok, Wahrnehmung ..., s. 67-68. 
zdolność prezydenta do sprawowania urzędu tylko w niewielkim stopniu, decyzja o ewentualnym przekazaniu zastępstwa jest kwestią decyzji prezydenta. Jeśli natomiast przyczyną jest choroba ciężka, wyłączająca zupełnie możliwość wykonywania obowiązków głowy państwa, wówczas - według formułowanych zaleceń - przewodniczący Bundestagu ma prawo sam, bez niczyjej zgody, ale też przy zachowaniu racjonalnej oceny rzeczywistości ${ }^{42}$, przejść do realizacji prezydenckich obowiązków. Kończąc ten wątek wskażmy jeszcze, że w razie sporu powstałego tle kwestii objęcia zastępstwa, doktryna dopuszcza, by przewodniczący Bundesratu, wobec istniejących wątpliwości, mógł wystąpić na drogę sporu kompetencyjnego w trybie art. 93 ust. 1 pkt 3 ustawy zasadniczej, gdzie organem rozstrzygającym jest Federalny Trybunał Konstytucyjny ${ }^{43}$.

W ustawie zasadniczej nie ma przepisów ograniczających okres trwania zastępstwa sede plena. Należy stąd wnosić, że trwa ono tak długo, jak długo trwa powodująca go przeszkoda. O wygaśnięciu mandatu zastępcy decyduje zatem ustanie danej przeszkody, ewentualnie wcześniejszy upływ kadencji urzędu głowy państwa. Co charakterystyczne, okres ten może się rozciągać na kilka dni, kilka miesięcy czy nawet kilka lat. Każdy z tych wariantów będzie się mieścił się ramach przyjętych unormowań prawnych. Automatyczne ograniczenie czasowe dotyczy natomiast zastępstwa sede vacante. Wynika ono z brzmienia art. 54 ust. 4 konstytucji, wprowadzającego zasadę, że na wypadek przerwania biegu kadencji prezydenta, w ciągu 30 dni od tego zdarzenia, przewodniczący Bundestagu zwołuje posiedzenie Zgromadzenia Federalnego, które ma za zadanie dokonania wyboru nowego prezydenta. $W$ takim stanie rzeczy zastępstwo wygasa z chwilą objęcia przez nowo wybranego prezydenta urzędu.

\section{Zakończenie}

Współczesny konstytucjonalizm wykształcił różne formy zastępstwa prezydenta w urzędzie. Koncepcja niemiecka, przyjęta na gruncie art. 57 ustawy zasadniczej z 1949 r., stanowi dość popularne rozwiązanie, oddają-

${ }^{42}$ Wynika to $\mathrm{z}$ faktu, iż inicjatywę prezydenta postrzega się jako zasadę, zaś inicjatywę przewodniczącego Bundesratu jako wyjątek od tej zasady; zob. R. Herzog, Art. 57...,., s. 7.

${ }^{43}$ Odnośnie do tego kierunku interpretacji przepisów niemieckiej ustawy zasadniczej zob. M. Bożek, Instytucja Prezydenta Republiki Federalnej Niemiec, Warszawa 2007, s. 84. 
ce funkcję prezydenckiego zastępcy organowi związanemu z legislatywa, co nie oznacza jednak, że jest ona pozbawiona pewnej specyfiki. Z całą pewnością element oryginalności nadaje tej konstrukcji fakt, że zgodnie z utrwalonym zwyczajem stanowisko przewodniczącego Bundesratu, a więc także prezydenckiego zastępcy, przypada w udziale szefowi rządu danego kraju związkowego. Powoduje to skomasowanie w rękach jednej osoby sporej liczby stanowisk, w efekcie czego wzmaga się ryzyko wystąpienia w określonych obszarach konfliktu ról. Z drugiej jednak strony, jak można sądzić, tak ukształtowany model zastępstwa wpisuje się w przyjętą w RFN zasadę federalnej struktury państwa. Pewnym problemem na tle obowiązującego stanu prawnego jest widoczne już na pierwszy rzut oka niedoregulowanie instytucji zastępstwa. Otóż zbyt mało precyzyjne postanowienia ustawy zasadniczej sprawiaja, że gdzieniegdzie pojawiają się interpretacyjne wątpliwości, które teoretycznie, mimo braku jak dotąd większych problemów, w przyszłej praktyce ustrojowej mogą okazać się wysoce kłopotliwe.

Słowa kluczowe: zastępstwo Prezydenta, zastępca Prezydenta, Prezydent Republiki Niemiec, Prezydent Republiki Federalnej Niemiec, Przewodniczący Bundesratu

\section{Bibliografia}

Anschütz G., Die Verfassung des Deutschen Reichs vom 11. August 1919 (Kommentar), Berlin 1929, art. 51;

Bożyk M., Instytucja Prezydenta Republiki Federalnej Niemiec, Warszawa 2007;

Butzer H., Art. 57 GG, [w:] B. Schmidt-Bleibtreu, F. Klein (red.), Kommentar zum Grundgesetz, Köln 2011;

Czarny P., Bundesrat. Między niemiecka tradycja a europejska przyszłościa, Warszawa 2000

Dunaj K., Weimarski model prezydentury, Warszawa 2010;

F. Stier-Somlo, Die Verfassungsurkunde der Vereinigten Staaten von Deutschland $<$ Demokratische Reichsrepublik> : ein Entwurf mit Begründung, Tübingen, 1919;

Fritsch K., Die Funktionen des Reichspräsidenten nach der neuen Reichsverfassung vom 11. August 1919 verglichen mit den Funktionen des ehemaligen deutschen Kaisers, Stettin 1921;

Hatscheck J., Deutsches und preussisches Staatsrecht, Berlin 1922;

Herrfahrdt H., Die Kabinettsbildung nach der Weimarer Verfassung unter dem Einfluss der politischen Praxis, Berlin 1927; 
Herzog R., Art. 57, [w:] T. Maunz, G. Dürig (red.), Grundgesetz. Kommentar, München 2014;

Hohhof T., Die Stellvertretung des Reichspräsidenten, Hamburg 1927;

Isensee J., Kirchhof P., Parlament Republiki Federalnej Niemiec, Warszawa 1995;

Mettke W., Die Verantwortlichkeit des Reichsgerichtsspräsidenten als Stellvertrete des Reichspräsidenten und deren Geltenmachung, Breslau 1934;

Paterok N., Wahrnehmung der Befugnisse des Bundespräsidenten durch den Präsidenten des Bundesrates, Artikel 57 GG, München 1966;

Pieroth B., Art. 57, [w:] H. Jarass, B. Pieroth (red.), Grundgesetz für die Bundesrepublik Deutschland, Aufl. 4, München 1997;

Pitschas R., Die Vertretung des Bundespräsidenten durch den Präsidenten des Bundesrates, Der Staat Bd. 12, 1973;

Stier-Somlo F., Deutches Reichs- und Landesstaatsrecht, Band 1, Berlin 1924;

Umbach D.C., Artikel 57, [w:] D.C. Umbach, T. Clemens (red.), Grungesetz. Mitarbeiterkommentar, Tom II, Art. 38-146 GG, Heidelberg 2002;

Wahl R., Stellvertretung im Verfassungsrecht, Berlin 1971;

Weisser G. Die Stellvertretung des Reichspräsidenten unter Berücksichtigung des ausländischen Staatsrecht, Kiel 1926.

\section{THE RULE OF THE VACANCY OF THE HEAD OF STATE \\ IN THE LIGHT OF ART.57 OF THE CONSTITUTION OF THE FEDERAL REPUBLIC OF GERMANY}

\section{S u m m a r y}

The article deals with the issue of the substitution of the President of the Federal Republic of Germany. Its first part involves a short outline of this institution by the time of Weimar Constitution of 1919. Next, there appears the relevant part of the text, which refers to the contemporary legal rules predicted by the Constitution of 1949. It touches upon three following problems, namely: 1) the legal position of the deputy President, 2) the so-called obstacles that cause disability of the President in holding his office, 3) the timeframe for playing a role of the substitute by the President of Bundesrat. Describing all these issues, the author formulates a thesis indicating that the present model of the substitution of the president suffers from being regulated not sufficiently detailed which may trigger serious interpretation troubles in the area of political praxis.

Keywords: the substitution of the President, a stand-in for the President, the President of the Federeal Republic of Germany, the President of Bundesrat 


\section{ФОРМУ ЛА ЗАМЕЩЕНИЯ ГЛАВЫ ГОСУДАРСТВА В СВЕТЕ СТ. 57 НЕМЕЦКОГО О СНОВНОГО ЗАКОНА}

\section{P е 3 го м}

В статье рассматриваются вопросы замещения Президента Федеративной Республики Германии. Первая часть содержит краткое описание механизмов, регулирующих данный вопрос в течение срока действия Конституции Веймарской Республики от 1919 г. На этом фоне анализируются действующие сегодня законы. Появдяются следующие вопросы: 1) системное положение заместителя президента, 2) препятствия в осуществлении полномочий президента, 3) срок действия полномочий для замещения президента. В своих исследованиях автор утверждает, что нынешняя модель замещения, которая функционирует в Германии, нуждается в лучшим урегулировании, что в практике может вызвать серьезные проблемы в интерпретации.

Ключевые слова: замещение Президента, заместитель Президента, Президент Федеративной Республики Германии, Председатель Бундесрата 